\title{
HAKIKAT PERKEMBANGAN DALAM KONSELING
}

\section{Ulfiah}

Fakultas Psikologi UIN Sunan Gunung Djati Bandung

Development is a set continuous progressive changes, systematic and accumulative. Progressive means that changes have a forward orientation, while systematic and continuous mean that all development's stage are related and cannot be separated from other phases. Traditionally human life development can be considered as a curved line, where those process generated very fast in prenatal, infant, and adolescence. This curved line would then step onto plateau which describes a stabil condition in adulthood and degrades when people aged. Developmental point of view in councellingin this case-were focused on individuals potential development including intellectual aspect, affective, social, emotional and religiousity aspect-thus, those individual will develop themselves to a higher level of development.

Keywords: Developmental, Councelling

\section{Pendahuluan}

Pendukung utama bagi tercapainya sasaran pembangunan manusia Indonesia yang berkualitas adalah pendidikan yang bermutu. Pendidikan yang bermutu dalam pelaksanaannya tidak cukup hanya dilakukan melalui transformasi ilmu pengetahuan dan teknologi, melainkan harus pula didukung oleh peningkatan profesionalisme dan sistem manajemen tenaga kependidikan serta pengembangan kemampuan individu untuk menolong diri sendiri dalam memilih dan mengambil keputusan demi pencapaian cita-citanya.

Kemampuan seperti itu tidak hanya berkaitan dengan aspek akademis, tetapi juga dengan perkembangan pribadi, sosial, kematangan intelektual dan sistem nilai individu itu sendiri. Berkaitan dengan pemikiran tersebut, dapatlah dipahami bahwa pendidikan yang ber- kualitas adalah pendidikan yang menghantarkan individu pada pencapaian standar akademis yang diharapkan dalam kondisi perkembangan diri yang sehat dan optimal sehingga individu tersebut mampu menyesuaikan diri dengan lingkungannya.

Harapan di atas, tentu tidak akan tercapai hanya dengan pengajaran baik di lembaga informal (keluarga), formal (sekolah), maupun non formal (masyarakat) akan tetapi pada pelaksanaannya diperlukan peran bimbingan konseling sebagai upaya membantu individu dalam pengembangan potensinya baik aspek intelektual, afektif, sosial, emosional, dan religius. Sehingga individu akan berkembang dengan nuansa yang lebih bermakna, harmonis, sosial dan bermanfaat. 


\section{Pengertian Hakikat dan Perkembangan}

Istilah "hakikat" dalam Kamus Besar Bahasa Indonesia berarti: intisari atau dasar; atau kenyataan yang sebenarnya (sesungguhnya). Sementara itu istilah perkembangan berarti serangkaian perubahan progresif yang terjadi sebagai akibat dari proses kematangan dan pengalaman. Seperti yang dikatakan oleh Daele "perkembangan berarti perubahan secara kualitatif. Ini berarti bahwa perkem-bangan bukan sekedar penambahan beberapa sentimeter pada tinggi badan seseorang atau peningkatan kemampuan seseorang, melainkan suatu prosese integrasi dari banyak struktur dan fungsi yang kompleks.

Istilah perkembangan (development) sering dicampur baurkan dengan "pertumbuhan" (growth). Walaupun kedua istilah tersebut nampaknya mempunyai gejala yang sama yaitu "perubahan", tetapi pada kenyataan berbeda.

Pertumbuhan digambarkan sebagai perubahan yang menyangkut segi kuantitatif, misalnya peningkatan dalam ukuran struktur fisik. Keadaan perubahan ini biasanya dapat diukur. Sedangkan perkembangan, digambarkan sebagai perubahan yang menyangkut segi kuantitatif dan kualitatif.

Perkembangan merupakan suatu rangkaian perubahan yang progresif, teratur dan berkesinambungan serta akumulatif. Pengertian progresif berarti perubahan mempunyai arah maju. Pengertian teratur dan berkesinambungan berarti dalam perkembangan terdapat hubungan antara setiap tingkat perkembangan dengan tingkat selanjutnya. Setiap perubahan yang terjadi tergantung pada perubah- an sebelumnya dan sebaliknya akan mempengaruhi perubahan yang akan datang.

Pada dasarnya ada dua proses perkembangan yang saling bertentangan yang terjadi secara serempak selama kehidupan, yaitu pertumbuhan atau evolusi dan kemunduran atau involusi. Keduanya mulai dari pembuahan dan berakhir dengan kematian. Dalam tahun-tahun pertama pertumbuhan berperan, sekalipun perubahan-perubahan yang bersifat kemunduran terjadi semenjak kehidupan janin.

Manusia tidak pernah statis. Semenjak pembuahan hingga ajal selalu terjadi perubahan, baik dalam kemampuan fisik maupun kemampuan psikologis. Piaget menjelaskan bahwa struktur itu" tidak pernah statis dan sudah ada semenjak awal". Dengan perkataan lain, organisme yang matang selalu mengalami perubahan yang progresip sebagai tanggapan terhadap kondisi yang bersifat pengalaman dan perubahan-perubahan itu mengakibatkan jaringan interaksi yang majemuk.

Secara tradisional jalannya perkembangan hidup manusia dianggap sebagai suatu garis kurva, dimana proses perkembangan itu berjalan dengan cepat selama masa prenatal, masa bayi, masa anak dan remaja, kemudian terjadi suatu plateu yang menggambarkan suatu stabilitas selama masa dewasa dan akhirnya terjadi penurunan pada masa tua. Adapun perkembangan ini berlaku untuk budaya, masyarakat, kelompok dan individu. 


\section{Tujuan Perubahan dalam Perkembangan}

Berbagai perubahan dalam perkembangan bertujuan untuk memungkinkan orang menyesuaikan diri dengan lingkungan dimana ia hidup. Untuk mencapai tujuan ini, maka realisasi diri atau yang biasanya disebut" aktualisasi diri" adalah sangat penting. Namun tujuan ini tidak pernah statis. Tujuan ini tidak pernah dianggap sebagai suatu dorongan untuk melakukan sesuatu yang tepat untuk dilakukan, untuk menjadi manusia yang diinginkan baik secara fisik maupun psikologis.

Adapun untuk mengungkapkan dorongan ini bergantung pada kemampuan-kemampuan bawaan dan latihan yang diperoleh tidak hanya selama masa anak-anak tetapi juga saat usianya meningkat dan sampai pada saat ia menjumpai tekanan-tekanan yang lebih besar untuk menyesuaikan diri dengan harapan-harapan masyarakat.

Realisasi diri memainkan peranan penting dalam kesehatan jiwa, maka orang yang berhasil menyesuaikan diri dengan baik secara pribadi dan sosial, harus mempunyai kesempatan untuk mengungkapkan minat, dan keinginannya dengan cara yang memuaskan dirinya. Tetapi pada saat yang sama harus menyesuaikan dengan standar-standar yang diterima. Kurangnya kesempatan-kesempatan ini akan menimbulkan kekecewaan dan sikapsikap negatif pada umumnya.

Faktor-faktor yang Mempengaruhi Sikap Terhadap Perubahan-perubahan dalam Perkembangan

1. Penampilan diri

2. Perilaku
3. Stereotip budaya

4. Nilai-nilai budaya

5. Perubahan peranan

6. Pengalam pribadi

\section{Prinsip-Prinsip Perkembangan}

1. Perkembangan merupakan hasil interaksi antara maturasi dan belajar

2. Pola-pola perkembangan: Setiap makhluk hidup akan mengikuti suatu pola tertentu sesuai dengan jenisnya

3. Ada perbedaan individual dalam perkembangan

4. Ada periode-periode dalam perkembangan (periode prenatal, infancy, bayi, periode anak, remaja, dewasa dan periode tua)

5. Ada tugas-tugas perkembangan pada setiap periode perkembangan.

\section{Fakta Penting Tentang Perkembangan}

Untuk memahami pola perkembangan, berbagai fakta tertentu yang sifatnya fundamental dan memiliki implikasi penting diantaranya:

1. Sikap kritis, fakta yang penting dan di awal perkembangan individu .

2. Kematangan dan belajar dalam perkembangan; Kematangan adalah terbukanya sifat-sifat bawaan individu, sedangakan belajar berasal dari latihan dan usaha pada pihak individu.

3. Perkembangan mengikuti pola yang tertentu dan yang dapat diramalkan, misalnya pola-pola teratur dari perkembangan fisik, motor, bicara dan perkembangan intelektual. 
4. Semua individu berbeda, seperti yang ditekankan oleh Dobzhansky "Setiap orang secara biologis dan genetis benar-benar berbeda satu dari yang lainnya, bahkan dari kasus bayi kembar".

5. Setiap tahap perkembangan mempunyai perilaku yang khas; Pola-pola itu ditandai dengan periode equilibrium, apabila individu dengan mudah menyesuaikan diri dengan tuntutan lingkungan dan akhirnya, berhasil mengadakan penyesuaian pribadi dan penyesuaian sosial dengan baik. Polapola itu ditandai dengan periode disequilibrium, apabila mereka mengalami kesulitan dalam penyesuaian yang mengakibatkan penyesuaian pribadi dan penyesuaian sosial menjadi buruk

6. Setiap tahap perkembangan mempunyai resiko; Ada bukti yang kuat bahwa setiap periode dalam rentang kehidupan dihubungkan dengan resiko perkembangan tertentu apakah berasal dari fisik, psikologis atau lingkungan maupun masalah-masalah penyesuaian yang tidak dapat dihindari

7. Perkembangan dibantu rangsangan; Walaupun sebagian besar perkembangan itu akan terjadi karena kematangan dan pengalaman-pengalaman dari lingkungan, masih banyak yang dapat dilakukan untuk membantu perkembangan seoptimal mungkin. Ini dapat dilakukan dengan merangsang perkembangan yang secara langsung mendorong individu untuk mempergunakan kemampuan yang terdapat dalam proses pengembangannya. Rangsangan ternyata paling efektif pada saat suatu ke- mampuan sedang berkembang secara normal, sekalipun disetiap saat juga penting

8. Perkembangan dipengaruhi oleh perubahan budaya, karena perkembangan individu dibentuk untuk menyesuaikan diri dengan standar-standar budaya dan segala hal yang ideal, maka perubahan-perubahan dalam standar tersebut akan mempengaruhi pola perkembangan misalnya tentang peran gender yang kadang masih dipersoalkan sebagian masyarakat tertentu

9. Harapan sosial pada setipa tahap perkembangan, setiap kelompok budaya mengharap anggotanya menguasai ketrampilan tertentu yang penting dan memperoleh pola perilaku yang disetujui pada berbagai usia sepanjang rentang kehidupan. Havighurst menamakannya tugas-tugas dalam perkembangan, yakni tugas yang muncul pada saat periode tertentu dari kehidupan individu yang jika berhasil akan menimbulkan rasa bahagia dan membawa kearah keberhasilan dalam melaksanakan tugastugas berikutnya. Akan tetapi jika gagal menimbulkan rasa tidak bahagia dan kesulitan dalam menghadapi tugas-tugas berikutnya

10. Keyakinan tradisional akan manusia pada semua tingkat usia., keyakinan akan ciriciri fisik dan psikologis ini mempengaruhi penilaian orang lain maupun evaluasi diri sendiri. Dalam kebudayaan kita, stereotip yang berhubungan dengan usia lanjut dapat mengakibatkan perlakuan yang kurang menyenangkan terhadap orang-orang dalam kehidupan masa tuanya. Diterima- 
nya stereotip ini oleh mereka yang berkembang menjadi tua menyebebkan ketidakbahagiaan selama usia tua dan juga merupakan faktor penting dalam penurunan fisik dan mental.

\section{Hakikat Perkembangan dalam Konseling}

Secara historis asal mula pengertian konseling adalah untuk memberi nasihat, seperti penasihat hukum, perkawinan dan penasihat kemah anak-anak pramuka. Kemudian nasihat itu berkembang ke bidang-bidang bisnis, manajemen, otomotif, investasi dan finansial.

Kemudian muncul English \& Inglish pada tahun 1958 mengemukakan arti konseling adalah: "Suatu hubungan antara seseorang dengan orang lain, dimana seorang berusaha keras untuk membantu orang lain agar memahami masalah dan dapat memecahkan masalahnya dalam rangka penyesuaian dirinya".

Di antara konseling yang muncul saat itu yang menonjol adalah konseling pendidikan, jabatan dan hubungan sosial. Biasanya yang menjadi klien adalah orang-orang normal dan juga dapat memasuki batas bidang psikoterapi.

Selanjutnya dalam era global dan pembangunan, maka konseling lebih menekankan pada pengembangan potensi individu yang dimilikinya, termasuk dalam potensi tersebut adalah aspek intelektual, afektif, sosial, emosional dan religius. Sehingga individu akan berkembang dengan nuansa yang lebih bermakna, harmonis, sosial, dan bermanfaat. Maka definisi konseling yang antisipasif sesuai tantangan pembangunan adalah:
"Konseling adalah upaya bantuan yang diberikan seorang pembimbing yang terlatih dan berpengalaman, terhadp individu-indivi yang membutuhkannya, agar individu tersebut berkembang potensinya secara optimal, mampu mengatasi msalahnya dan mampu menyesuaikan diri terhadap lingkungan yang selalu berubah."

Konseling adalah upaya membantu individu melalui proses interaksi yang bersifat pribadi antara konselor dan konseli agar konseli mampu memahami diri dan lingkungannya, mampu membuat keputusan dan menentukan tujuan berdasarkan nilai yang diyakininya sehingga konseli merasa bahagia dan efektif perilakunya.

Lebih jauh, Pietrofesa dan kawan-kawan menunjukkan sejumlah ciri-ciri konseling profesional sebagai berikut :

1. Konseling merupakan suatu hubungan professional yang diadakan oleh seorang konselor yang sudah dilatih untuk pekerjaannya itu

2. Dalam hubungan yang bersifat profesional itu, klien mempelajari ketrampilan pengambilan keputusan, penyelesaian masalah, serta tingkah laku atau sikap-sikap baru.

3. Hubungan professional itu dibentuk berdasarkan kesukarelaan antara klien dan konselor.

ASCA (American School Counselor Assosiation) mengemukakan, bahwa konseling adalah hubungan tatap muka yang bersifat rahasia, penuh dengan sikap penerimaan dan pemberian kesempatan dari konselor kepada klien. Konselor mempergunakan pengetahuan 
dan ketrampilannya untuk membant klien mengatasi masalah-masalahnya.

Adanya perbedaan definisi konseling tersebut, selain ditimbulkan karena perkembangan ilmu konseling itu sendiri, juga disebabkan oleh perbedaan pandangan ahli yang merumuskannya tentang konseling dan aliran atau teori, yang kemudian dikelompokkan kedalam beberapa model kategori pula. Ada ahli yang mengklasifikasikan konseling berdasarkan fungsinya menjadi tiga kelompok, yaitu suportif, reedukatif, dan rekonstruktif. Konseling juga dibedakan berdasarkan metodenya, yaitu metode direktif dan non direktif. Osipow, Walsh, dan Torsi (1980) mengelompokkan konseling berdasarkan kawasan atau ranah perilaku yang merupakan kepeduliannya, yaitu konseling yang berorientasi pada ranah kognitif dan konseling yang berorientsi pada ranah afektif. Ahli lain Patterson (1966) secara lebih rinci mengelompokkan pendekatan konseling menjadi lima kelompok, yaitu pendekatan rasional, teori belajar, psikoanalitik, perceptual-fenomenologis, dan eksistensial.

Uraian tersebut menggambarkan betapa sulit merumuskan definisi konseling yang komprehensif dan berlaku untuk setiap orang dari berbagai aliran. Namun demikian, berikut ini diuraikan beberapa generalisasi yang menggambarkan karakteristik utama kegiatan konseling.

1. Konseling merupakan salah satu bentuk hubungan yang bersifat membantu. Makna bantuan itu sendiri, yaitu sebagai upaya untuk membantu orang lain agar ia mampu tumbuh kearah yang dipilihnya sendiri, mampu menghadapi masalah yang dihadapinya dan mampu menghadapi krisiskrisis yang dialami dalam kehidupannya. Tugas konselor adalah menciptakan kondisi-kondisi fasilitatif yang diperlukan bagi pertumbuhan dan perkembangan klien.

2. Hubungan dalam konseling bersifat interpersonal. Hubungan konseling terjadi dalam bentuk wawancara secara tatap muka antara konselor dengan klien. Hubungan itu tidak hanya bersifat kognitif dan dangkal, tetapi melibatkan semua unsur keperibadian dari kedua belah pihak yang meliputi pikiran, perasaan, pengalaman, nilainilai, kebutuhan, harapan, dan lain-lain. Dalam proses konseling, kedua belah pihak hendaknya menunjukkan kepribadian yang asli. Hal ini dimungkinkan karena konseling itu dilakukan secara pribadi dan dalam suasana rahasia

3. Keefektifan konseling sebagian besar ditentukan oleh kualitas hubungan antara konselor dan kliennya. Dilihat dari segi konselor, kualitas hubungan itu bergantung pada kemampuannya dalam menerapkan teknik-teknik konseling dan kualitas pribadinya.

Dari keseluruhan pengertian konseling yang ada, disimpulkan, bahwa yang menjadi tujuan konseling pada umumnya dan disekolah pada khususnya adalah sebagai berikut:

1. Mengadakan perubahan perilaku pada diri klien sehingga memungkinkan hidupnya lebih produktif dan memuaskan. Khusus untuk setting sekolah, Boy dan Pine (Depdikbud, 1983) menyatakan, bahwa 
tujuan konseling adalah membantu siswa menjadi lebih matang dan lebih mengaktualisasikan dirinya, membantu siswa maju dengan cara yang positif, membantu dalam sosialisasi siswa dan memanfaatkan sumber-sumber dan potensinya sendiri. Persepsi dan wawasan siswa berubah, dan akibat dari wawasan baru yang diperoleh, maka timbullah pada diri siswa reorientasi positif terhadap kepribadian dan kehidupannya.

2. Memelihara dan mencapai kesehatan mental yang positif. Jika hal ini tercapai maka individu mencapai integrasi, penyesuaian, dan identifikasi positif dengan yang lainnya. Ia belajar menerima tanggung jawab, berdiri sendiri, dan memperoleh integrasi perilaku

3. Penyelesaian masalah. Hal ini berdasarkan kenyataan, bahwa individu-individu yang mempnyai masalah tidak mampu menyelesaikan sendiri masalah yang dihadapiya. Disamping itu, biasanya siswa datang kepada konselor karena ia percaya bahwa konselor dapat membantu menyelesaikan masalahnya

4. Mencapai keefektifan pribadi. Sehubungan dengan ini, Blocher mengatakan, bahwa yang dimaksud dengan pribadi yang efektif adalah pribadi yang sanggup memperhitungkan diri, waktu dan tenaganya, serta bersedia memikul resiko-resiko ekonomis, psikologis, dan fisik. Ia tampak memilki kemampuan untuk mengenal, mendefinisikan, dan menyelesaikan masalah-masalah. Ia tampak konsisten terhadap dan dalam situasi peranannya yang khas. Ia tampak sanggup berfikir secara berbeda dan orisinil, yaitu dengan cara-cara yang kreatif. Ia juga sanggup mengontrol dorongan-dorongan dan memberikan respons-respons yang wajar terhadap frustrasi, permusuhan dan ambiguitas

5. Mendorong individu mampu mengambil keputusan yang penting bagi dirinya. Disini, jelas bahwa pekerjaan konselor bukan menentukan keputusan yang harus diambil oleh klien atau memilih alternatif dari tindakannya. Keputusan-keputusan ada pada diri klien sendiri. Ia harus tau mengapa dan bagaimana ia melakukannya. Oleh sebab itu, klien harus belajar mengestimasi konsekuensi-konsekuensi yang mungkin terjadi dalam pengorbanan pribadi, waktu, tenaga, uang, risiko, dan sebagainya. Individu belajar memerhatikan nilai-nilai dan ikut mempertimbangkan yang dianutnya secara sadar dalam pengambilan keputusan. Karakteristik konseling untuk pengembangan adalah:

1. Konselor/pembimbing selalu berusaha melihat individu dan dari sinilah dimulai penjelajahan dalam proses konseling. Akan tetapi bukan sebaliknya, bahwa seorang konselor hanya melihat sisi kelemahan/ problem/kesulitan klien belaka. Akibatnya proses konseling dipandang oleh para klien adalah suasana yang tidak menyenangkan

2. Jika sekiranya klin memiliki masalah/ kelemahan atau kesulitan, biarlah klien yang mengungkapkannya berkat dorongan dari konselor. Kemudian konselor ber- 
upaya membantu agar klien mampu mengatasi masalahnya.

3. Konselor berusaha dengan menggunakan keterampilan, keperibadian dan wawasannya, menciptakan situasi konseling yang kondusif bagi pengembangan potensi klien.

4. Konselor berusaha memberikan kesempatan kepada klien untuk memberikan alternatif-alternatif pilihan yang sesuai dengan kondisi dan situasi dirinya. Konselor akan ikut membantu agar klien dapat mempertimbangkan alternatif-alternatif secara realistik.

5. Konseling pengembangan berjalan melalui proses konseling yang menggairahkan, menggembirakan klien, yaitu melalui dialog/wawancara konseling yang menyentuh hati nurani dan kesadaran klien.

6. Konselor dituntut agar dapat membaca bahasa tubuh yang berkaitan dengan lisan klien atau bahasa tubuh yang memberikan isyarat tertentu yang mengandung arti tertentu.

Dari uraian di atas, jelaslah bahwa untuk merealisasikan efektifitas konseling sangat dibutuhkan seorang konselor yang profesional, tidak cukup hanya memiliki ilmu, keterampilan, dan keperibadian belaka, akan tetapi harus pula mengimplementasikan kode etik konseling (KEK), diantaranya:

1. Memantapkan hubungan konseling

2. Menghormati perbedaan dalam hal ini seorang konselor mampu untuk tidak diskriminasi dan menghormati perbedaan

3. Menghormati hak-hak klien.
Tabel perbedaan Konseling Pengembangan (Orientasi Baru) dan Konseling Gaya Lama:

\begin{tabular}{|c|c|}
\hline $\begin{array}{c}\text { Konseling Pengembangan } \\
\text { (Orientasi Baru) }\end{array}$ & $\begin{array}{c}\text { Konseling Gaya } \\
\text { Lama } \\
\end{array}$ \\
\hline $\begin{array}{l}\text { - Bersifat Paedagogis } \\
\text { - Melihat potensi klien bu- } \\
\text { kan kelemahan } \\
\text { - Berorientasi pengem- } \\
\text { bangan potensi positif } \\
\text { klien } \\
\text { - Menggembirakan klien } \\
\text { - Dialog konselor menyen- } \\
\text { tuh klien } \\
\text { - Klien terbuka } \\
\text { - Bersifat humanistik- } \\
\text { religius } \\
\text { - Klien sebagai subjek me- } \\
\text { megang peranan, memu- } \\
\text { tuskan tentang dirinya } \\
\text { - Konselor hanya memban- } \\
\text { tu dan memberi alterna- } \\
\text { tif- alternatif }\end{array}$ & $\begin{array}{ll}\text { - } & \text { Bersifat klinis } \\
\text { - } & \text { Melihat } \\
& \text { kelemahan klien } \\
\text { - } & \text { Berorientasi pe- } \\
\text { mecahan masalah } \\
\text { klien } \\
\text { - } & \text { Konselor serius } \\
- & \text { Klien sering } \\
& \text { tertutup } \\
- & \text { Dialog menekan } \\
& \text { perasaan klien } \\
- & \text { Klien sebagai } \\
& \text { objek }\end{array}$ \\
\hline
\end{tabular}

Jika dilihat dari konsep konseling diatas, pada hakikatnya proses konseling adalah membantu individu agar dapat mengembangkan potensinya secara optimal dengan kata lain dapat menjadi individu yang fungsional, mencapai integritas diri dan aktualisasi diri sehingga mampu memecahkan masalah dan mampu menyesuaikan dirinya terhadap lingkungannya.

Dengan melihat hakikat konseling diatas, seorang konselor diharapkan mampu:

1. Menangkap isu sentral atau pesan utama klien; Konselor seharusnya segera dapat menangkap isu utama (masalah) klien. Jika klien datang kepada konselor, ia akan bercerita tentang diri dan masalahnya. Seperti bagaimana ia dapat menjadikan dirinya seorang penerbang yang handal, apa yang mungkin dikembangkan dari dirinya sehingga ia menjadi orang yang berguna dan populer, bagaimana perasaan rendah dirinya dapat teratasi, ada apa dengan hu- 
bungan sosial klien dengan orang lain, ada sesuatu kesalahan dalam upaya belajarnya sehingga prestasi tidak menguntungkan, dan lain sebagainya. Dari isu-isu tersebut konselor harus mampu menangkap isu utama yang menjadi masalah penting klien.

2. Utamakan tujuan klien-tujuan konseling. Dalam proses konseling jangan terjadi konselor mengutamakan tujuannya sendiri, sedangkan tujuan klien diabaikan. Tanggung jawab utama konselor adalah mendorong klien untuk mengembangkan potensi, kekuatan,otonomi, dan kemampuan mengatur/mengarahkan nasibnya sendiri. Dengan kata lain tujuan klien adalah tujuan konseling itu sendiri.

Secara umum dikatakan bahwa tujuan konseling haruslah mencapai:

1. Effective daily living, artinya setelah selesai proses konseling klien harus dapat menjalani kehidupan sehari-harinya secara efektif dan berdaya guna untuk diri, keluarga, masyarakat, bangsa, dan agamanya.

2. Relationship with other, artinya klien mampu menjalin hubungan yang harmonis dengan orang lain di keluarga, sekolah, kantor, masyarakat dan lingkungan lainnya.

Melihat realitas hidup, tak dapat dipungkiri bahwa klien mempunyai berbagai tujuan di dalam konseling. Tujuan-tujuan yang beragam telah dikemukakan oleh pakar konseling sebagai berikut:

1. Maslow (1971), Rogers (19610; Selfactualization, artinya tujuan konseling adalah agar tercapai aktualisasi diri sebagai manifestasi potensi yang dimiliki klien. Dalam aktualisasi ini tidak terlepas dari sosialisasi potensi klien yang dikembangkan tidak bertentangan dengan nilai dan norma yang berlaku di masyarakat. Di samping itu dalam aktualisasi diri terdapat unsur kemampuan untuk memilih yang terbaik dengan mempertimbangkan aspek-aspek lingkungan.

2. Schultz (1967), Mosher \&Sprithall (1971): Personal growth and personal development, yakni tujuan konseling agar tercapai pertumbuhan dan perkembangan klien berdasarkan potensi yang dimilikinya;

3. Berne (1964), Haris (1967): Okayness, yakni tujuan konseling yang dibutuhkan klien adalah terjadinya harmonisasi hubungan antar sesama dalam kehidupan;

4. Carkhuff (1969), Gordon (1967): effectiveness, yakni tujuan konseling adalah seorang klien akan mampu bekerja dan hidup lebih efektif dalam segala hal, seperti, berkarya, berkeluarga dan sebagainya;

5. Konseling Islami, menetapkan tujuan konseling bahwa dalam kehidupan haruslah hubungan sesama manusia itu dilandasi oleh keimanan, kasih sayang, saling menghargai, dan berupaya saling membantu berdasarkan iman kepada Allah SWT.

\section{Simpulan}

Dari uraian pembahasan dapat diambil beberapa kesimpulan, sebagai berikut:

1. Perkembangan berarti serangkaian perubahan progresif yang terjadi sebagai akibat 
dari proses kematangan dan pengalaman.

Berbagai perubahan dalam perkembangan bertujuan untuk memungkinkan individu menyesuaikan diri dengan lingkungan di mana ia hidup. Untuk mencapai tujuan ini, maka realisasi diri atau yang disebut "aktualisasi diri" adalah sangat penting. Namun tujuan ini tidak pernah statis. Tujuan dapat dianggap sebagai suatu dorongan untuk melakukan sesuatu yang tepat untuk dilakukan, untuk menjadi manusia yang diinginkan baik secara fisik maupun psikologis.

2. Untuk merealisasikan tujuan hidup individu agar dapat menghadapi tantangan pembangunan dibutuhkan peran konseling, karena konseling merupakan upaya bantuan yang diberikan seorang pembimbing yang terlatih dan berpengalaman, terhadap individu-individu yang membutuhkannya, agar individu tersebut berkembang potensinya secara optimal, mampu mengatasi masalahnya dan mampu menyesuaikan diri dengan lingkungannya.

3. Karakteristik konseling untuk pengembangan diantaranya; Berusaha melihat potensi individu dalam proses konseling, mempercayai klien untuk mengemukakan masalahnya, untuk menciptakan situasi konseling yang kondusif haruslah memiliki keterampilan, wawasan dan keperibadiannya, konselor berusaha memberikan kesempatan kepada klien untuk memberikan alternatif-alternatif pemecahan masalahnya, menciptakan konseling yang menggairahkan juga menggembirakan klien me- lalui dialog/wawancara konseling yang menyentuh hati nurani dan kesadaran klien dan konselor dituntut mampu membaca bahasa tubuh yang mengandung arti tertentu.

\section{Daftar Pustaka}

Nurikhsan, A. Juntika. (2006). Bimbingan dan Konseling dalam Berbagai Latar Belakang kehidupan, Bandung: Refika Aditama.

Geldard, David. (1989). Basic Personal Counselling. Prentice Hall

Hurlock, Elizabeth B. (1980) Developmental Psicology. New York: MC Graw Hill Book Company.

Lerner, L.M. (1976). Human Deve-lopment A life Span perspective, New York: MC Graw Hill Book Company.

Cavanagh, Michael E. (1982). The Counseling Experience, A Theoretical and Practical Approach California: Brooks/Cole Publishing Company.

AM. Moelono, dkk. (1993). Kamus Besar Bahasa Indonesia. Jakarta: Departemen Pendidikan dan Kebudayaan, Balai Pustaka.

Miller, Patricia H. (1993). Theories Of Developmental Psycology. New York: W.H. Freemen and Company

Willis, Sofyan (2004). Konseling Individual, Teori dan Praktek Bandung: Alfabeta. 